Engineering History and Heritage

Volume 165 Issue EH4

Reconstruction of the Neues Museum in

Berlin, Germany

Eisele and Seiler

ice | proceedings
Proceedings of the Institution of Civil Engineers

Engineering History and Heritage 165 November 2012 Issue EH4

Pages 221-233 http://dx.doi.org/10.1680/ehah.11.00013

Paper 1100013

Received 26/04/2011_Accepted 30/03/2012

Published online 13/10/2012

Keywords: buildings, structures \& design/conservation/

foundations

ICE Publishing: All rights reserved

\title{
Reconstruction of the Neues Museum in Berlin, Germany
}

1 Gerhard Eisele Prof. Dipl.-Ing. Associate Partner, Ingenieurgruppe Bauen, Karlsruhe, Germany; Professor, University of Applied Sciences, Potsdam, Germany
2 Josef Seiler Dipl.-Ing.

Partner, Ingenieurgruppe Bauen, Karlsruhe, Germany
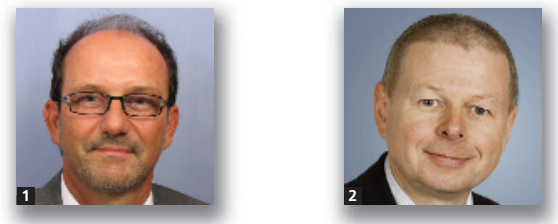

Construction engineers are increasingly faced with tasks in which a balance must be struck between historic structural designs and modern use requirements. Although they usually master these challenges, a thorough understanding of historic structures and conservation objectives is not widespread. However, such an understanding is key for proper handling of buildings with high conservation significance. In the case of the reconstruction of the Neues Museumin in Berlin, Germany, the most important responsibility of the engineers was to recognise, at an early stage, that purely theoretical approaches would not deliver the intended result and that all parties involved in the project needed to engage in the discussions, which also had to be facilitated. Key services to be provided included the development of verification concepts, planning and designing the required tests in a cross-disciplinary approach and coordinating the activities with the supervising authority.

\section{Introduction}

The Neues Museumin in Berlin, Germany was built from 1841 to 1859 under the management of Friedrich August Stüler, a pupil of Karl-Friedrich Schinkel. Although designed with a solid appearance to the outside observer, the building's interiors were a compelling combination of the latest cast-iron technology and ancient lightweight construction techniques. Even the particularly well-organised and systematic building process in the shell construction phase might serve as a good example for some sites of today. However, shortly after its opening, the museum building began to show settlement damage. This settlement activity persisted and reached a depth of $40 \mathrm{~cm}$ at the most unfavourable location.

In 1943, during the Second World War, the central staircase hall was bombed out. The north-west wing, the Egyptian courtyard and the south-east dome suffered the same fate in 1945. Some parts of the building were left fully exposed to the elements for over 40 years. The significance of the remaining fabric was recognised in the mid-1980s, prompting a decision to reconstruct the Neues Museum; however, significant portions of the damaged building sections had to be demolished.

Initial work to stabilise the foundations and the building fabric had begun even before the reunification of Germany. Planning and design of the reconstruction commenced in 1998 and the first construction work started in 2003. The structural work was completed in 2008 and the museum reopened in October 2009.

This article describes some of the aspects relevant to the work of the construction engineers who dealt with the historic fabric in the course of planning the reconstruction. Nowadays, a single engineer or even a group of engineers is no longer capable of mastering such tasks alone. This type of project requires a number of experts from various fields.

Some historic structures are unsuitable for a formal evaluation solely based on generally accepted verification methods or modern codes and standards. For this reason, experimental methods had to be considered at an early stage in order to support the structural stability analysis required for the historic elements (Steffens, 2001). The verification methodology was defined at the concept planning stage and implemented experimentally in close cooperation with Prof. Steffens, Ingenieurgesellschaft mbH (PSI), Bremen.

\section{Problems with the foundations and their restoration}

Neues Museum is located on an island in the middle of the River Spree, which runs through the heart of Berlin (Figure 1). 


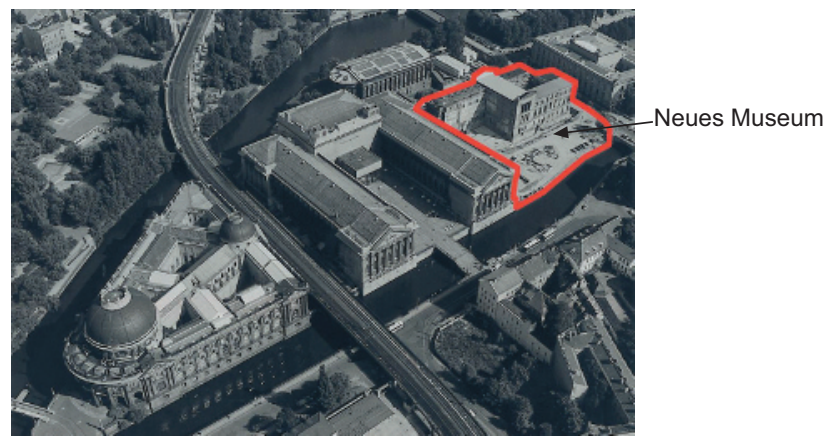

Figure 1. Aerial photograph of Museum Island, Neues Museum (provided by Planungsgruppe Museumsinsel)

The ground is characterised by unconsolidated Holocene inclusions in the otherwise sound Pleistocene bedrock, which is typical of its location in the Berlin-Warsaw glacial valley. Of all the buildings on Museum Island, Neues Museum is particularly affected by this inhomogeneity. The structurally stable ground has a downward gradient from the south-east to the north-west corner, where it lies approximately $25 \mathrm{~m}$ below the bottom edge of the foundation (Figure 2).

This situation was known when the original building was constructed - an attempt was made at resolving the issue by inserting a wooden pile foundation. However, since the length of the wooden piles was limited, the north-west area rested on a 'floating' pile foundation (Figure 3), which began to cause damage to the building shortly after its opening in 1855 due to uneven settlement. This damage required subsequent repair. The situation was exacerbated by the fact that the groundwater level was lowered several times for extended periods during construction of nearby buildings. As a result, the pile foundation and top wooden grid became infested, which triggered irreversible rotting of the grid and the pile heads.

\subsection{Restoration of the foundations}

A pile-supported foundation slab in the area of the former north-west wing and the new foundations for the adjoining walls had been cast prior to the reunification of Germany. After reunification, Ingenieurgruppe Bauen was commissioned with continuing this work.

The first task was to assess the structure that had been inserted to transfer loads from the masonry to the new piles. Part of the remedial work carried out before reunification was the insertion of a 'high-tech' structure comprising stainless steel block connectors and prestressed steel ties; however, this placed high peak loads on the historic brickwork (Figure 4).

Ingenieurgruppe Bauen then proposed a 'robust' design (Figure 5) that required less drilling in the original building fabric, enabled the use of standard structural steel and reduced the amount of stress transferred to the historic brickwork. The relevant structural and economic factors were carefully considered, and the new robust design was chosen for the remaining walls.

Small composite bored piles were used (consisting of steel pipes and reinforced concrete) that had been classified as a special

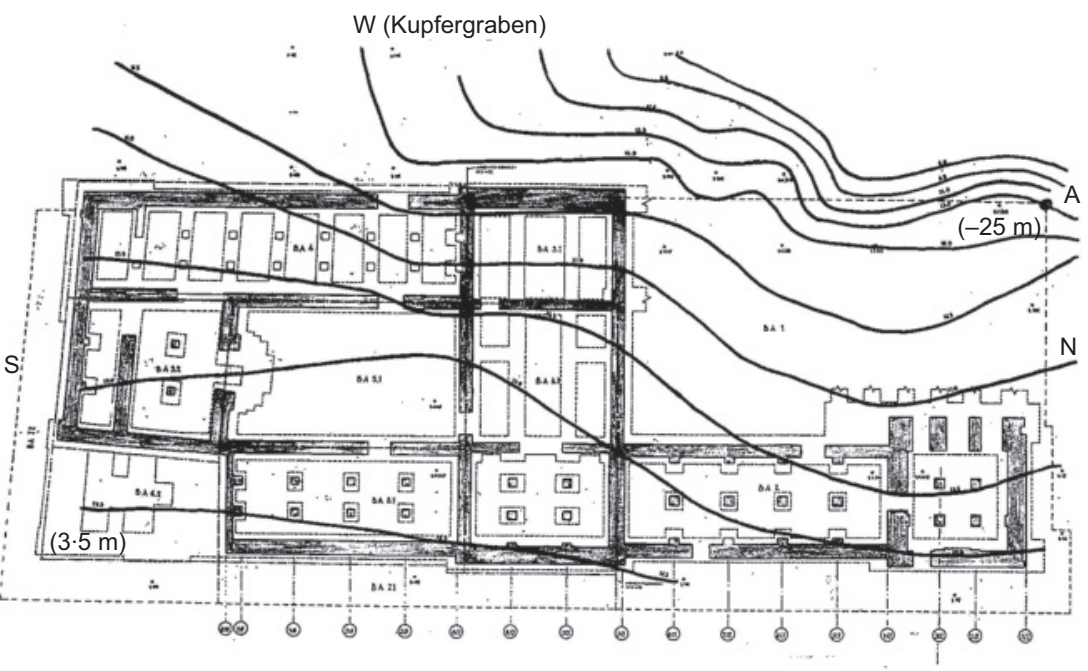

Figure 2. Levels of the structurally stable ground, approximately 3.5 to $25 \mathrm{~m}$ below the bottom of the foundation (courtesy of Ingenieurgruppe Bauen) 


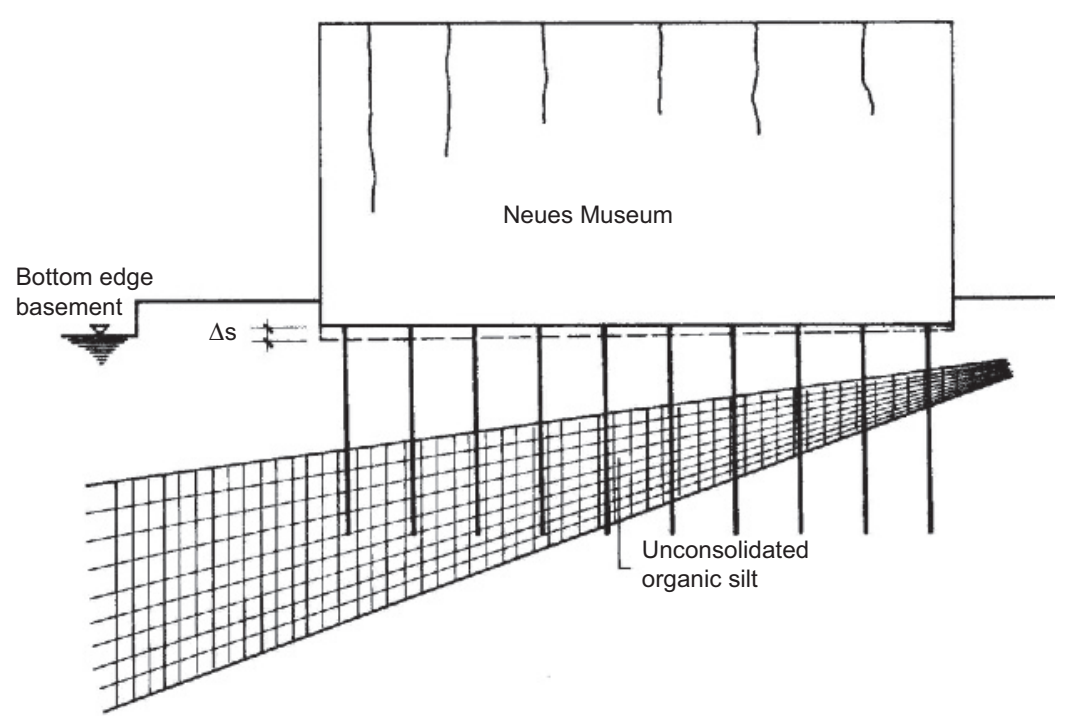

Figure 3. 'Floating' pile foundation resulting in crack formation in walls due to uneven settlement ( $\Delta \mathrm{s}$, differential settlement)

design in East Germany and which were constructed as tubular piles with a national technical approval after the reunification of Germany. From 1990 to 1994, 2568 piles in lengths ranging from 9 to $32 \mathrm{~m}$ were inserted, corresponding to a total length of approximately $50 \mathrm{~km}$.

\section{Settlement measurements and building stabilisation}

A comprehensive series of measurements was carried out simultaneously with the foundation work in order to monitor movements of the building during these activities and to

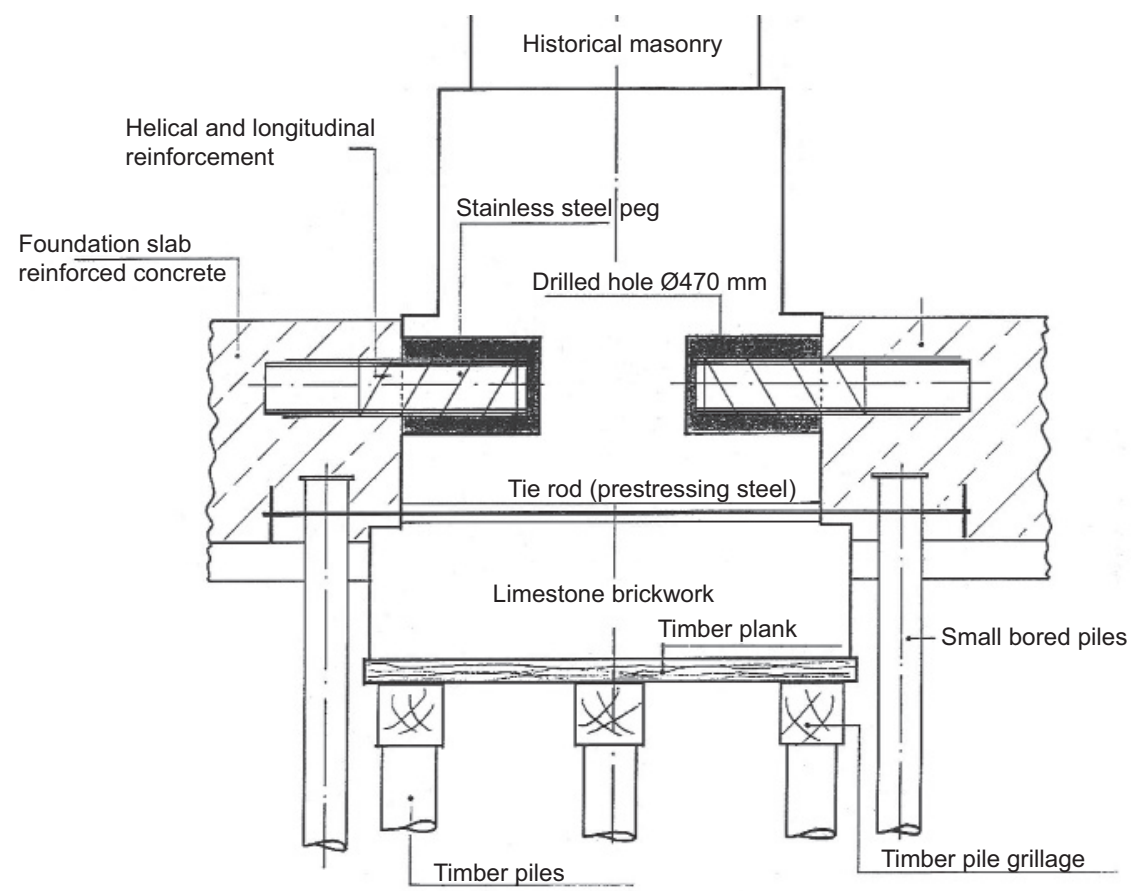

Figure 4. 'High-tech' load-transfer structure (courtesy of Ingenieurgruppe Bauen) 


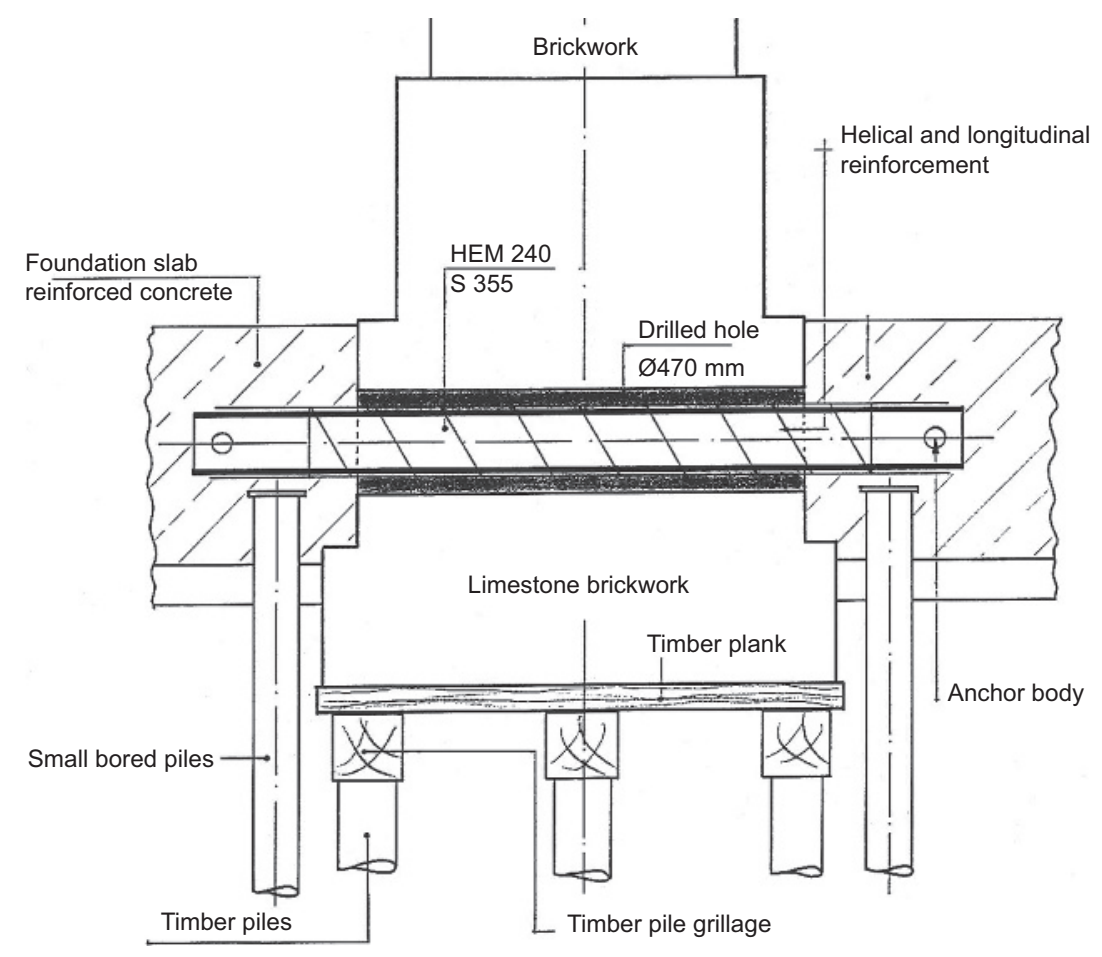

Figure 5. 'Robust' load-transfer structure (courtesy of

Ingenieurgruppe Bauen)

stabilise it in the event of any disruptive movements due to drilling. After the reunification of Germany, these measurements were systematically analysed with a view to stabilising the building fabric. These measurements are being continued using a correspondingly adapted measurement programme.

A comparison of the values measured at significant points during the construction work yielded the following findings.

- Drilling work inevitably increased the rate of settlement for a certain period.

- The settlements could be considered 'accelerated' phenomena that would have occurred over time in an uncontrolled manner.

- The movement patterns of certain parts of the building that occurred due to damage previously caused by the inhomogeneous ground were revealed even more clearly by the drilling work. Remedial measures for stabilising the building were derived from these patterns.

- After the foundation slab had been installed, identical settlements were measured for the foundation slab and the walls, showing that the load-transfer structure is effective.

- Secondary settlements that occurred after hardening of the foundation slab were minor. Differences in settlement between neighbouring measuring points remain within reasonable limits and can be compensated by the building fabric.

- Reconstruction work should aim to maintain the achieved uniformity of settlement and deformation.

- Minor local damage caused by differences in settlement cannot be excluded.

\subsection{Stabilisation of the building fabric}

While the stabilisation work was being planned and executed, there was still no concept for the final reconstruction of the building. For this reason, planning and implementation followed the principle of stabilising the respective existing condition while avoiding any restrictions for reconstruction. Furthermore, as far as reasonably possible, all new work should be either reversible or reusable for the reconstruction.

One immediate remedial activity was to consolidate cracks that posed a risk to the structural stability of the building. The following work was performed once settlements had ceased.

Settlement-induced gaps between individual shear walls and building sections were closed.

Detached stiffening walls were reincorporated in the overall structure. 
Engineering History and Heritage

Volume 165 Issue EH4
Reconstruction of the Neues

Museum in Berlin, Germany

Eisele and Seiler
For reasons of building physics (weather protection), as many as possible of the smaller, structurally less significant cracks were also consolidated.

In a final step, the walk-on stability of the surviving ceilings had to be examined and secured for the interim period (Eisele and Seiler (1999) give a comprehensive report on this topic).

\section{Aspects of structural design during reconstruction}

As a result of the industrial revolution in England, the Neues Museum was one of the first prestigious buildings in Berlin in which the use of iron became a distinct feature in both structural and architectural terms. Because of the issues that arose from the unstable ground, dead loads had to be minimised and masonry ceilings built on 'clay pots' were thus used.

Given the history of the building, most parts of the surviving original ceilings were found to be in astonishingly good structural condition. However, real problems arose in some of the floor bays where weather exposure had damaged the fabric or where significant sagging occurred in central sections due to the removal of lateral supporting members.

The client requested that all ceilings should be upgraded to fulfil current requirements so that they could withstand service loads of up to $5 \mathrm{kN} / \mathrm{m}^{2}$ in accordance with DIN 1055 . Estimates and information given in the original building documentation give rise to the assumption that load-bearing capacities of $200 \mathrm{~kg} / \mathrm{m}^{2}\left(2 \mathrm{kN} / \mathrm{m}^{2}\right)$ were considered sufficient at the time of construction (Hoffmann, 1846). The structural design aimed to preserve the historic structures as a technical monument and to return them to their original purpose, as undisturbed as possible, while also responding to the client's requests. The remaining original structures took priority so that the exhibition layout could be adjusted to the specific situation as and when required.

Structurally supporting members, such as large sections of the iron structures, were evaluated using modern verification concepts. The investigations revealed that some of these structures provided significant load-bearing reserves for their original purpose.

\subsection{Assessment of the load-bearing capacity of clay pot ceilings}

The concave design of the ceiling areas was based on an ancient technique that used cylindrical, completely closed, hollow clay 'bricks' laid in gypsum mortar, which were referred to as 'clay pots' in the project documents. This method provides an extremely low weight per unit area at remarkably high loadbearing capacities (Figures 6-8).

The clay pots were manufactured with only $7-10 \mathrm{~mm}$ thick walls and lids. They were used as 'bricks' for various purposes, again held together with a gypsum mortar. Among other features, this construction method was used for the calotte ceilings consisting of transverse arches and brickwork pendentives interspaced with spherical domes of around $4.5 \mathrm{~m}$ in diameter (Figure 6), barrel vaults with 5-6 m spans (Figures 7, 9 and 10) and vaulted ceilings between steel beams.

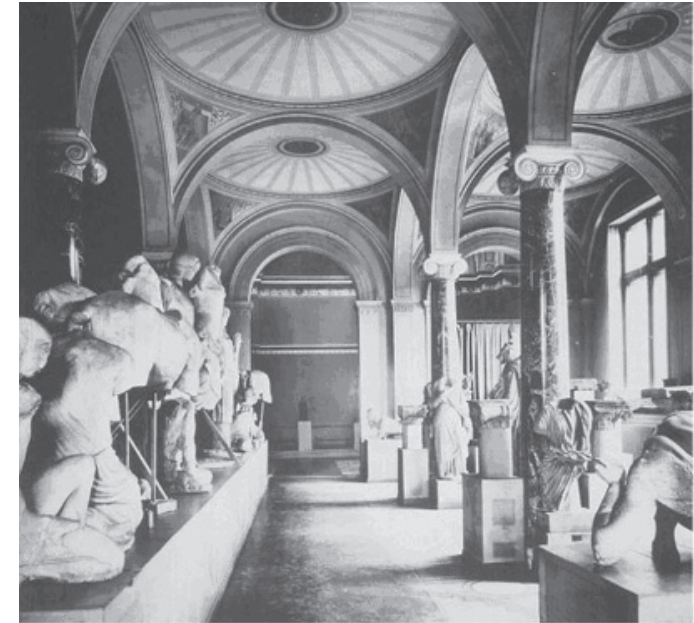

(a)

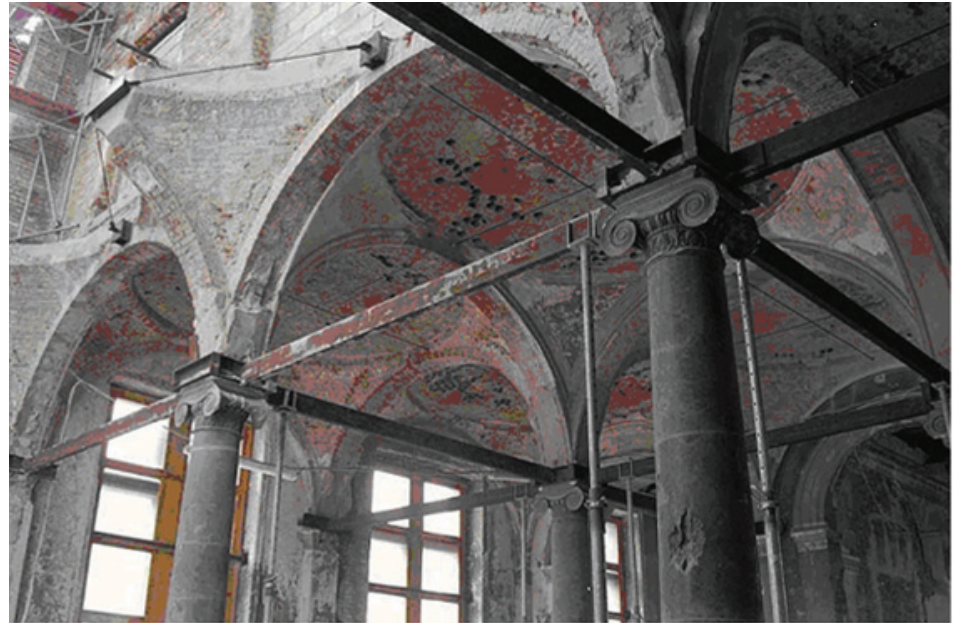

(b)

Figure 6. (a) Calotte ceiling consisting of clay pots. (b) Condition prior to reconstruction (courtesy of Ingenieurgruppe Bauen) 


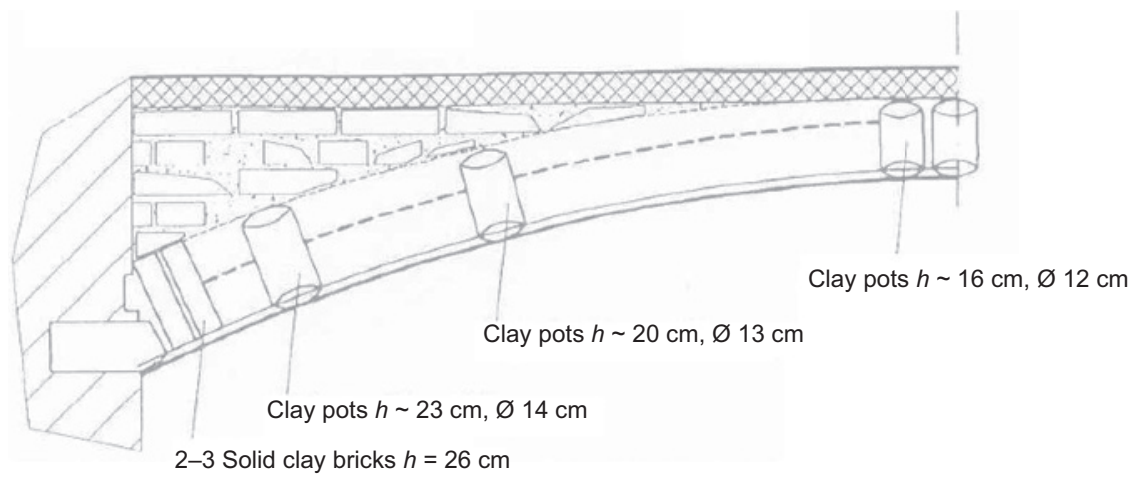

Figure 7. General structure of a clay pot vault (courtesy of Ingenieurgruppe Bauen)

\subsubsection{Structural analysis}

In the initial step, the loads acting on the existing clay pot ceiling systems (calotte ceilings, barrel vaults and vaulted ceilings) were estimated on the basis of preliminary calculations. For this purpose, assumptions had to be made regarding material characteristics such as the modulus of elasticity, loadbearing capacity and stiffness of the system. All reference documents found in the literature were used. The analyses of a historical load test performed on a single-bay vault (Hoffmann, 1846) were compared with the results of a calculation using a 3D finite-element (FE) model. Parametric studies carried out for structurally determinate subsystems were used to vary the derived assumptions for the material characteristics and to analyse the results of the calculations.

The basic findings from this work were as follows.

- The highest loads acting on the clay pot structures are in the barrel vaults.

Due to the relatively low dead loads, the effects of loads that vary from bay to bay ('kinematics') must also be

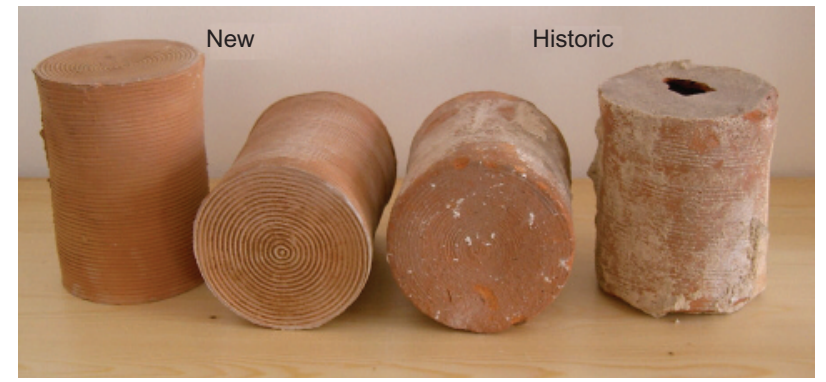

Figure 8. New and historic clay pots (courtesy of Ingenieurgruppe Bauen) considered for the barrel vaults because they form multibay systems.

- The design can be interpreted as a combination of two load-bearing effects: a diaphragm effect in the plane of the pot lids and a more flexible honeycomb structure in the cross-section.

- The service loads that the ceilings may potentially withstand cannot be determined without supplementary experimental tests.

\subsubsection{Experimental tests}

The findings of the structural analysis were used to develop the following programme for estimating the load-bearing capacity of the clay pot ceilings.

Preliminary load test on an existing four-bay barrel vault to identify the system.

- Basic tests on small specimens with associated numerical analyses.

Load test on a newly built sample vault.

- Development of an appropriate computation model and structural verifications for all clay pot systems.

- Confirmation of the computation model, and thus of the load-bearing capacity, using load tests in selected locations.

- Inclusion of the plaster floor forming part of the historic ceilings in the load-bearing capacity analysis and evaluation of its contribution to the ceiling areas to be reconstructed.

\subsubsection{Preliminary load test on an existing four-bay barrel vault (Figure 9)}

A four-bay barrel vault with spans of approximately $6 \mathrm{~m}$ was chosen for the preliminary load tests. Two bays were alternately loaded in order to analyse the stiffness of the overall system, deformation behaviour, the modulus of 


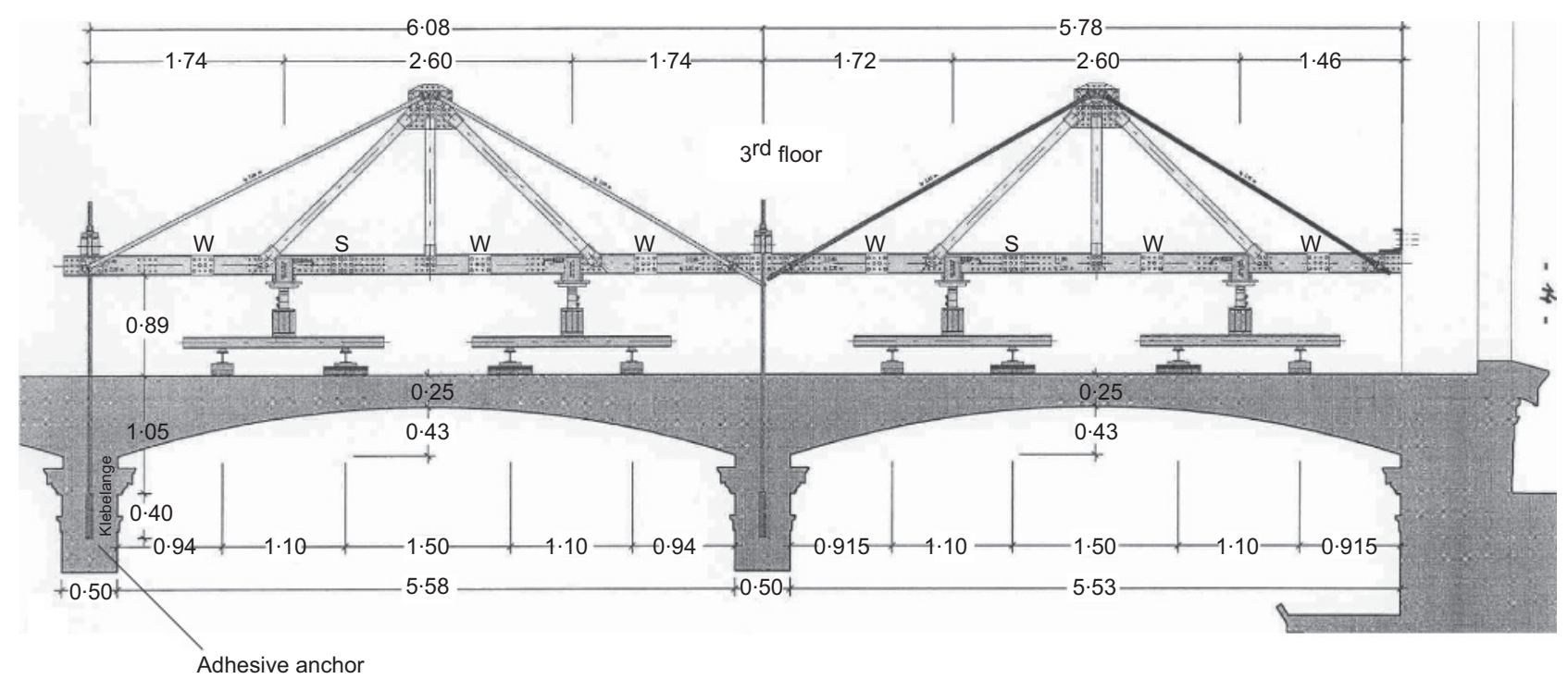

Figure 9. Loading test on historic barrel vault; schematic view (provided by PSI, Bremen). Dimensions in metres

elasticity of the clay pot mortar matrix, torsion of the transverse arches, continuity effect and biaxial structural effect.

Mobile load frames were used to generate service loads that varied from bay to bay.

Online measuring equipment and an associated acoustic emission analysis (AEA) were used to ensure that the testing was non-destructive. The system for a subsequent FE calculation was derived from the measured deformation and deflection values.

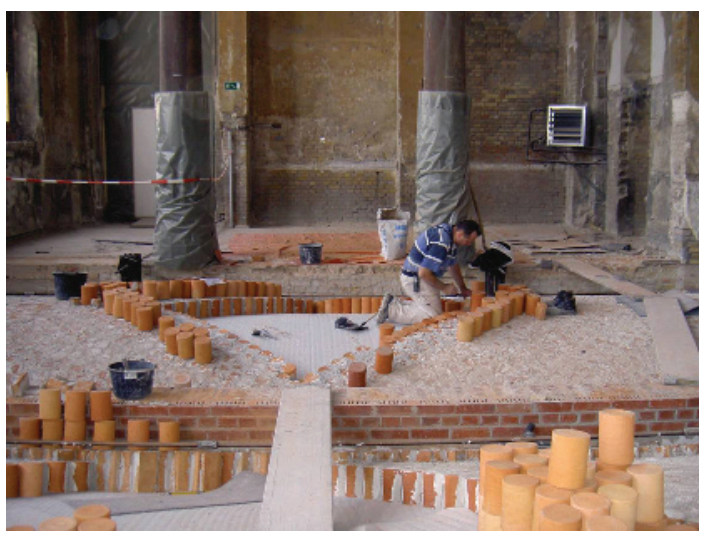

(a)

Figure 10. (a) Construction of a barrel vault on falsework. (b) Soffit view after removal of falsework (courtesy of Ingenieurgruppe

Bauen)

\subsubsection{Basic tests on small specimens}

In addition to conserving and repairing the existing ceilings, two of the originally seven bays of a barrel vault system were to be complemented by five new clay pot floor bays replicating the original design. This meant that the clay pots and the gypsum mortar mixes had to be selected so as to ensure that their mechanical properties and appearance largely corresponded to the original materials. To achieve this goal, laboratory tests were conducted on about 30 small specimens of various 'pots' and mortars in different combinations and load cases. An AEA of these small specimens was performed for calibration purposes.

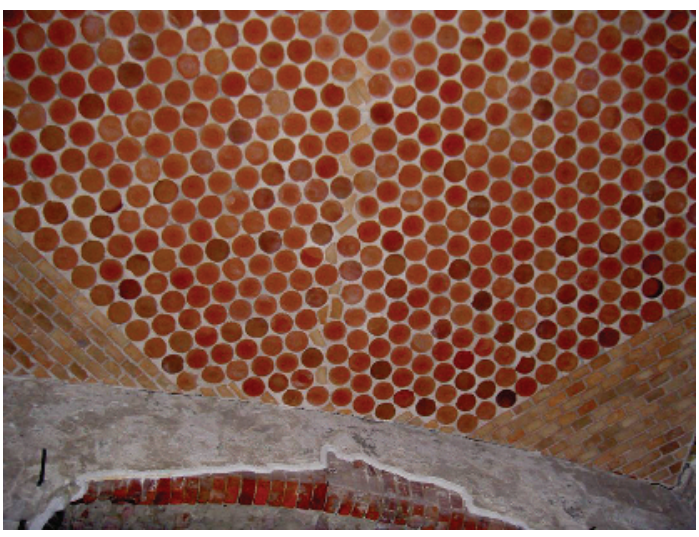

(b) 
Reconstruction of the Neues

Museum in Berlin, Germany

Eisele and Seiler

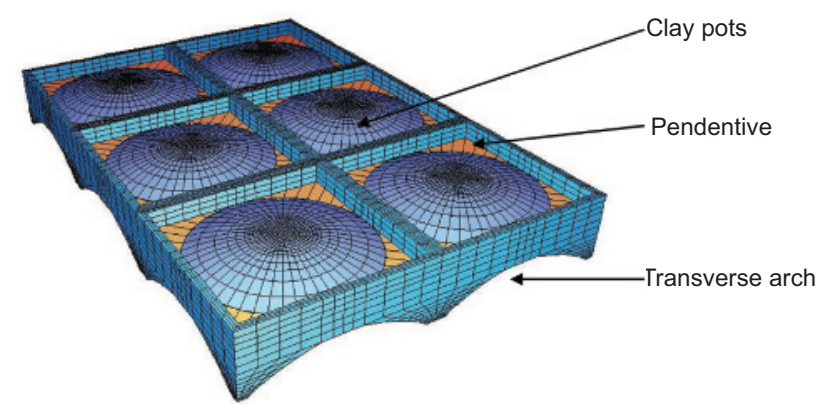

Figure 11. 3D FE model, six-bay system with transverse arch and pendentive viewed from the top (courtesy of Ingenieurgruppe Bauen)

The materials ultimately used for the reconstruction work were selected on the basis of these tests. The tests and associated calculations with a refined model based on an elastoplastic material law were used to prove the existence of a redundant structural system. After failure of the rigid outer shell (i.e. pot lids breaking away), the load shifts to the honeycomb structure formed by the pot walls and the mortar within the cross-section; this is associated with a corresponding increase in deformation.

\subsubsection{Sample vault}

Since the original vault could not be used for limit load tests, a new full-scale two-bay sample vault was constructed within the building. This structure also provided an opportunity to test specific techniques and work sequences. In the first test series, the effect of a partially load-bearing plaster layer was investigated. A supplementary load-bearing plaster floor was included in subsequent testing. The structure was loaded to failure in the course of the second series of measurements and included the structural effect of the plaster. The results complemented the values calculated for the existing and newly designed floor bays (Figures 10 and 11) and ultimately confirmed that the load-bearing capacities were sufficient for museum use.

\subsection{Assessment of the load-bearing capacity of the limestone columns}

Columns made of various natural stones (sandstone, limestone, marble) were used in the central axes of the individual exhibition rooms (Figures 6 and 12). In addition to their dead loads, the columns are subjected to higher service loads resulting from museum operation and, to a certain extent, to increased loads due to the construction of an additional floor to accommodate building services and installations under the roof. The condition of the individual column sections is significant because various weather conditions had affected the materials (which were not necessarily suitable for outdoor use) during the long period of neglect as an unprotected ruin. Thus, columns with Carrara marble capitals and bases and limestone shafts (Figure 12) had to be examined more thoroughly. Most

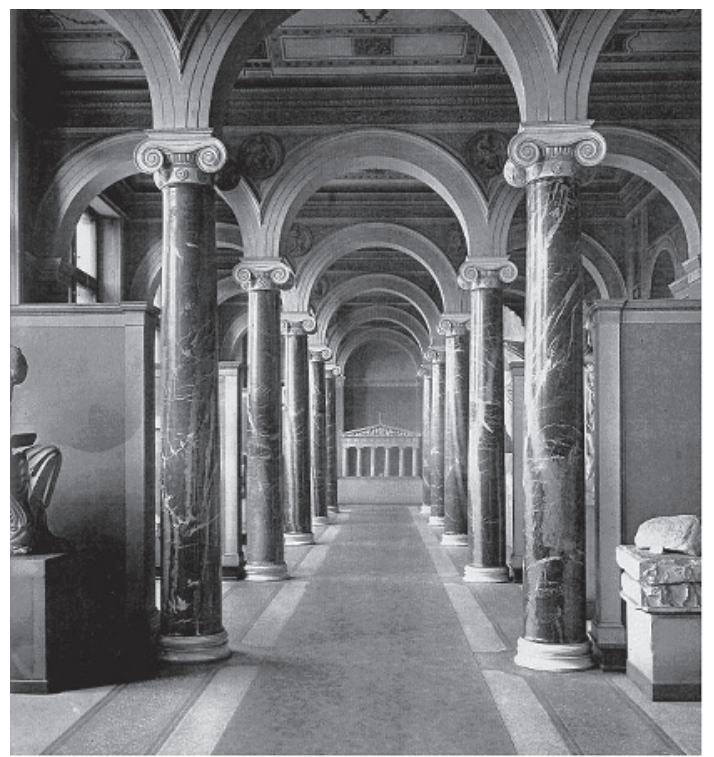

(a)

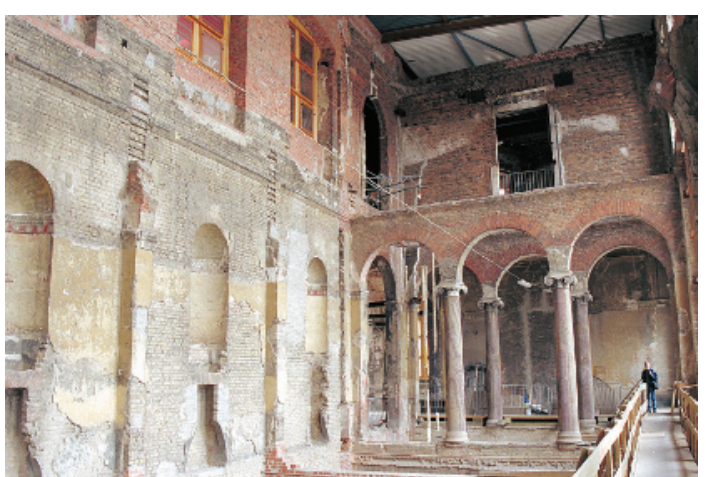

(b)

Figure 12. (a) Historic column arrangement with barrel vault (courtesy of Ingenieurgruppe Bauen). (b) Condition prior to reconstruction 
Engineering History and Heritage

Volume 165 Issue EH4
Reconstruction of the Neues

Museum in Berlin, Germany

Eisele and Seiler

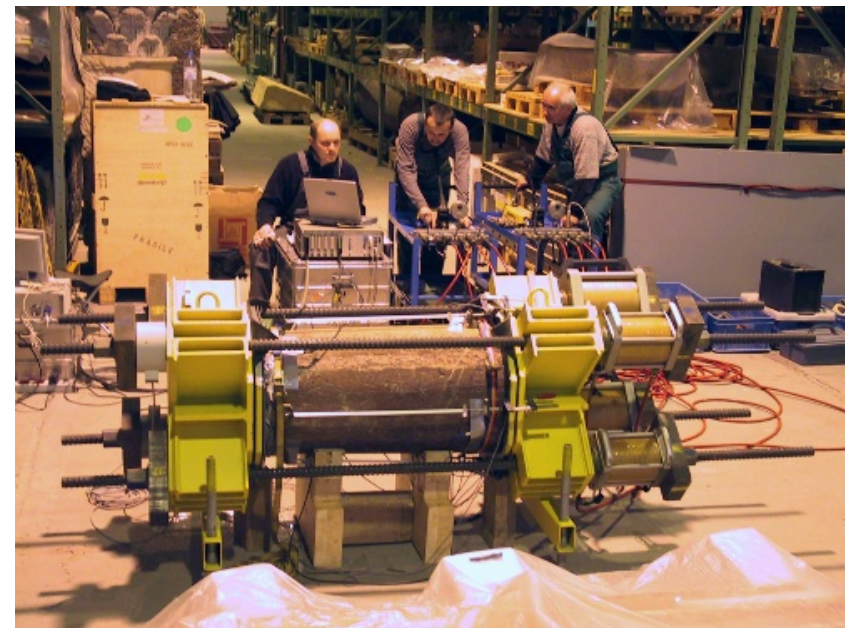

Figure 13. Test set-up for column fragment in the storage facility (courtesy of Ingenieurgruppe Bauen)

of the columns are still in their original positions. Two undamaged columns and the fragments of four broken columns had been put into storage.

The shafts consist of 'Pyrenean marble', which is a limestone of the 'marbre campan melange' variety. This material is not homogeneous; its external surfaces show veins in various colours and orientations (Figures 12-14). The original documents revealed that remedial work was necessary even before their original installation in order to repair transport damage.

Initial ultrasonic and georadar measurements delivered reference values that made it possible to classify the existing items.

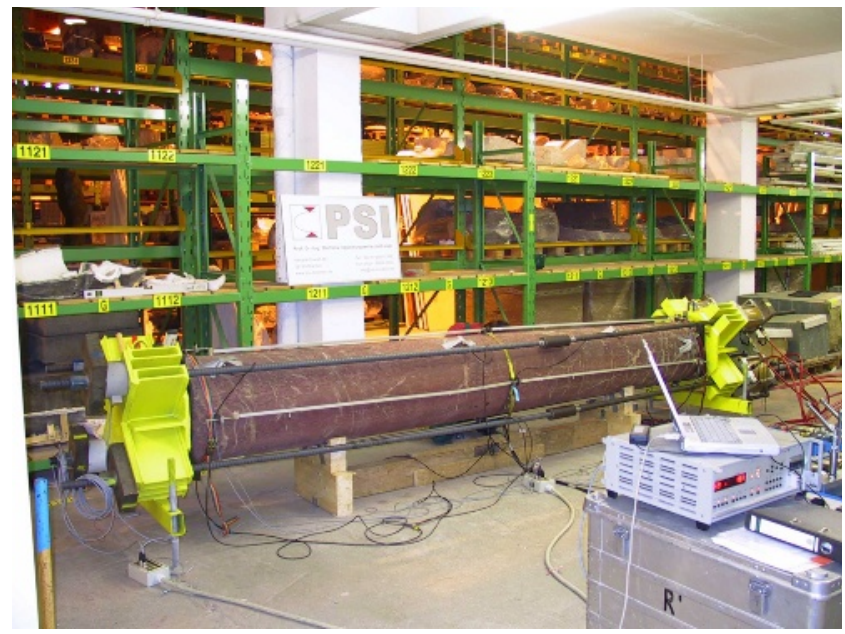

Figure 14. Test set-up with horizontal column shaft in the storage facility (courtesy of Ingenieurgruppe Bauen)
However, even at this stage, theoretical verifications alone were insufficient because the internal load-bearing behaviour could not be captured adequately by an idealised model. The degree of interlocking and geometrical shape differ from joint to joint, which is why they are not accurately reflected in the calculations. Again, it appeared useful to combine theoretical verifications with experimental tests.

Specially prepared 'drums' made of column fragments salvaged in the course of the demolition work in the 1980s were subjected to concentric and eccentric loads. AEA was used for a more accurate determination of their load-bearing potential and both non-destructive and limit load tests were carried out (Figure 13). In the next step, a mobile test rig was used, again in an AEA-controlled setting, to subject the two column shafts to concentric and eccentric service loads that were increased by inclusion of a safety factor (Figure 14).

Although sufficient load-bearing capacity was found for concentric loading, the permissible load had to be limited for even minor eccentricities owing to the inhomogeneous structure of the limestone. Conversely, this meant that the entire structure would withstand the actual loads if eccentricities could be kept minor during load application.

In the next series of tests, further column shafts identified as particularly critical in the course of the preliminary examinations were successfully tested in situ in a vertical position using appropriately modified loading devices (Figures 15 and 16). Due to the reduction in load-bearing capacity detected for eccentric loading, the existing geometric inhomogeneities in the columns were measured on site and directly applied to the computational verifications. A comparison with the eccentricities reached in the tests using specific load scenarios then made it possible to calculate the permissible load-bearing capacity with sufficient accuracy.

\subsection{Reinforcement of cast-iron girders with CFRP sheets}

In keeping with the trend of the time, the original building was constructed with many cast-iron components. This is unproblematic wherever such structural members are loaded mainly in compression. However, cast-iron sections were also used as 'joists', between which the infill brickwork could be inserted very easily to form vaulted ceilings. These joists are subjected to bending with a marked tensile bending zone, which is why they also had to be verified for the service loads required by modern use patterns. The tensile strength of the original cast iron amounts to only $30-40 \%$ of its compressive strength. Inhomogeneities caused by the manufacturing process (shrinkage cavities) weaken the tension zones, thus leading to a dangerous susceptibility to brittle failure. 
Engineering History and Heritage

Volume 165 Issue EH4
Reconstruction of the Neues

Museum in Berlin, Germany

Eisele and Seiler

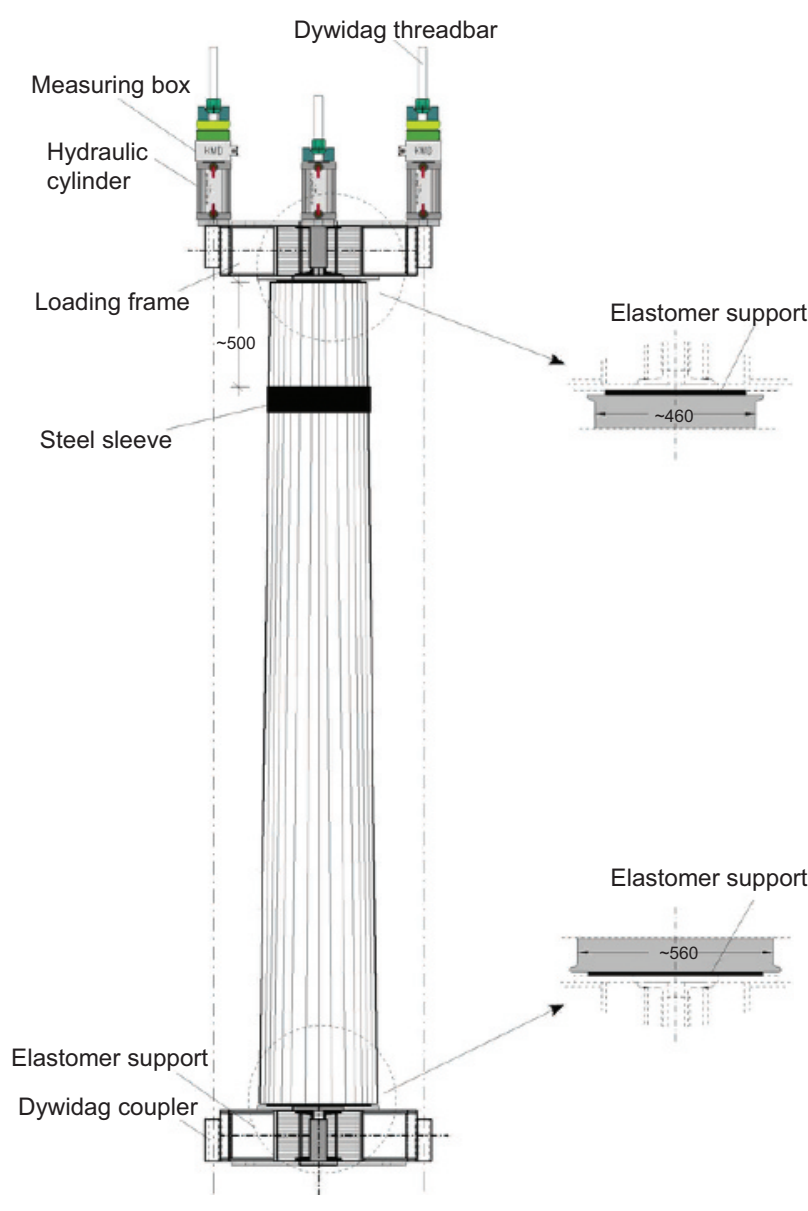

(a)

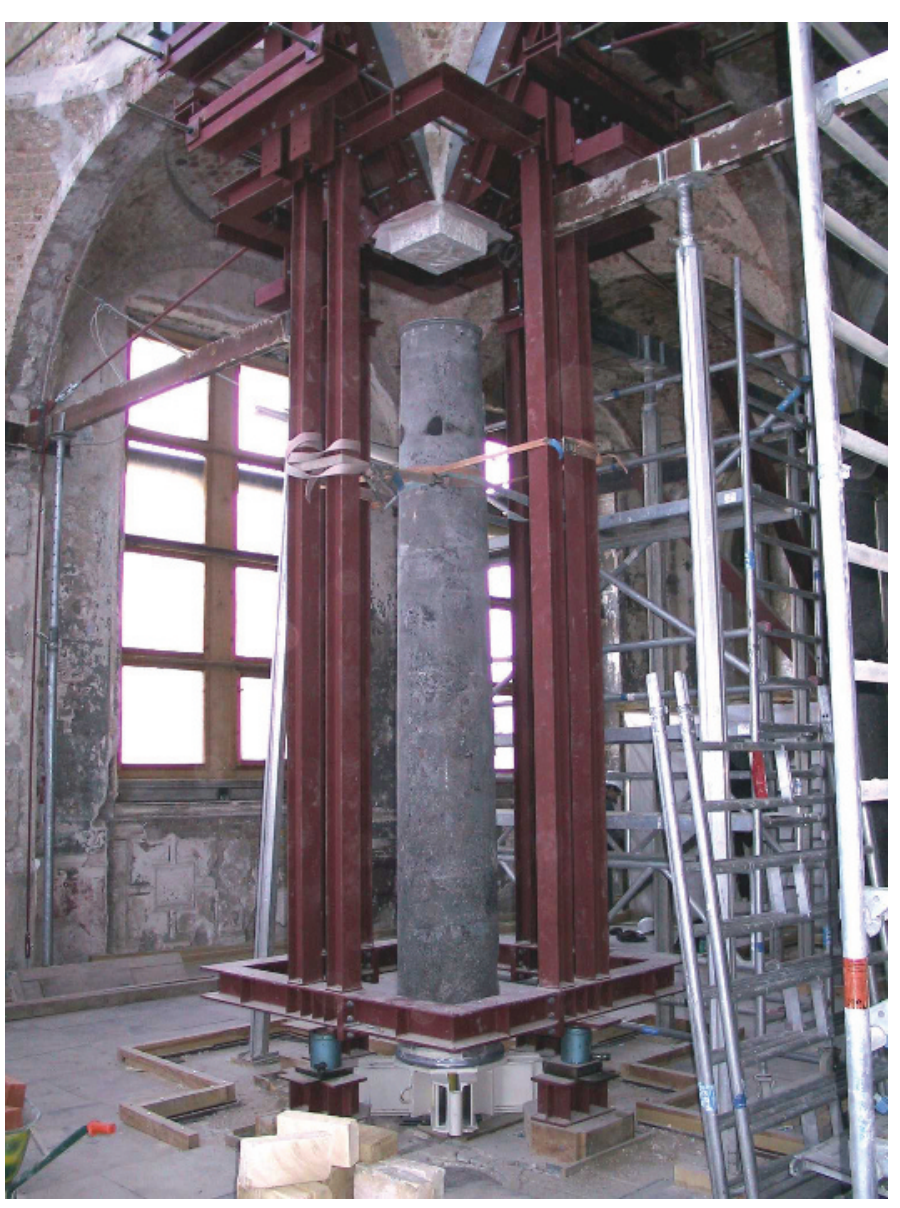

(b)

Figure 15. (a) Test set-up for column shaft with loading frame, schematic view and site situation with emergency support (dimensions in mm) (provided by PSI, Bremen). (b) Base, capital and ornamentation were removed, bottom loading frame in installed position (courtesy of Ingenieurgruppe Bauen)

Approximate calculations using design methods specified in the literature (Frey and Käpplein, 1993) resulted in theoretically permissible service loads between 1.0 and $2 \cdot 0 \mathrm{kN} / \mathrm{m}^{2}$ assuming undamaged structural components - quite optimistic given the history of the building. These values were insufficient if the building is to be used as a museum.

Historic cast iron cannot be welded and bolted steel fish plates were not an option owing to the shape of the elements. One possible solution was to reinforce the iron with carbon fibre reinforced plastic (CFRP) sheets in the tensile zone (Figure 17). This method is widely known in concrete construction and complies with conservation requirements because mechanical interventions in the member to be reinforced are not necessary. In addition, installation of the reinforcement is reversible.
No prior experience existed regarding reinforcement measures for this combination of materials. For this reason, a verification concept was developed jointly with the Institute of Concrete Construction and Fire Protection at Braunschweig University of Technology. This concept is based on the method used for nonreinforced beams developed by Frey and Käpplein (1993).

The first step was to obtain basic information on the behaviour of cast-iron beams. New beams were cast for this purpose. In our 'high-tech' society, it is not at all easy to produce grey cast iron to the lower quality standard equivalent to the original condition. The beams were partially damaged prior to testing and subjected to experiments to determine their load-bearing capacities in the reinforced and non-reinforced condition (Figure 18). 


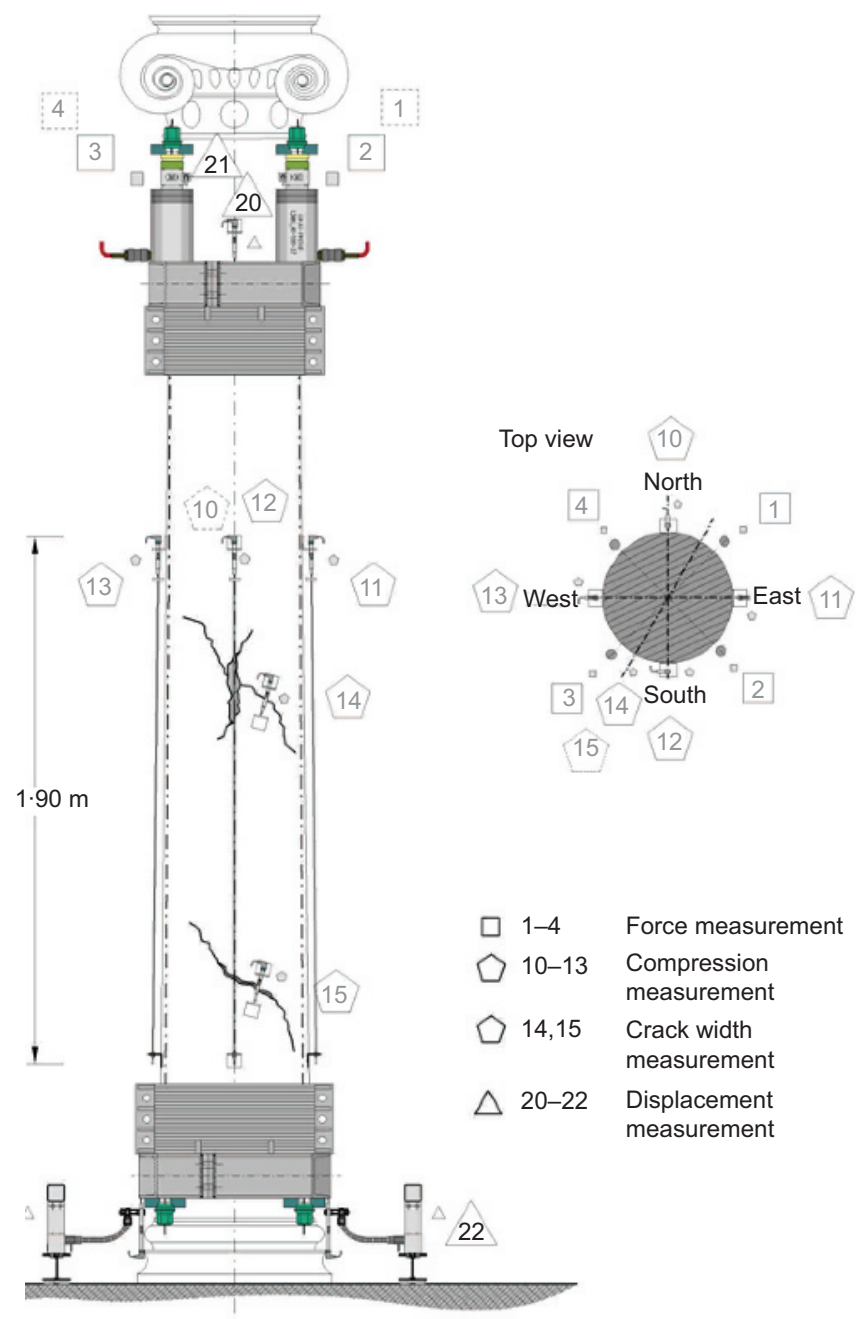

(a)

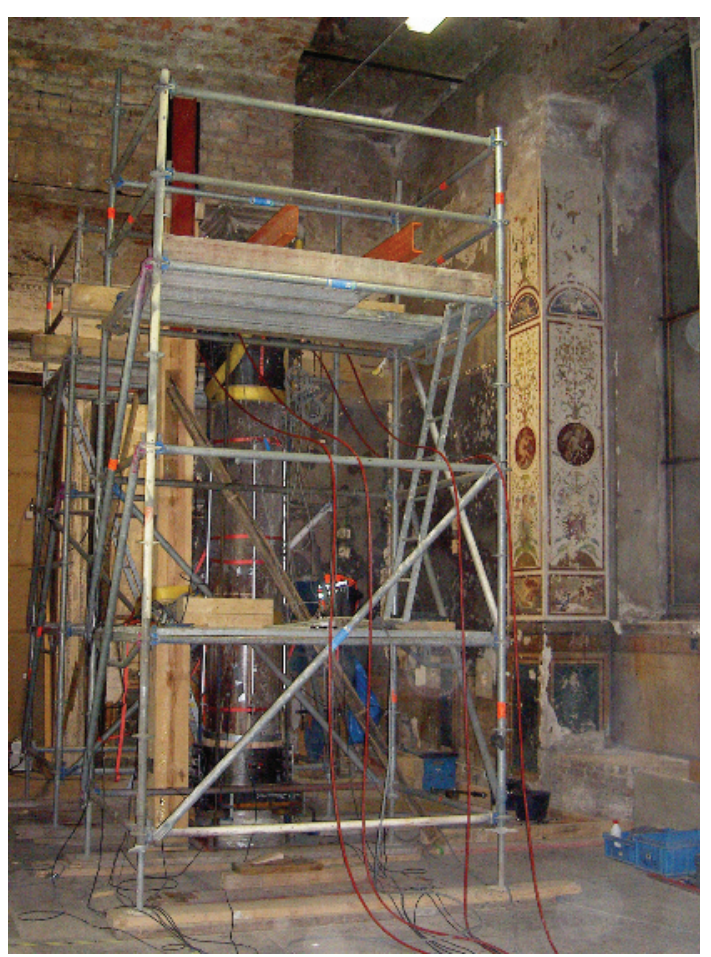

(b)

Figure 16. (a) Test set-up for fractured column shaft with historic repair (provided by PSI, Bremen). (b) Application of external test load component using load introduction rings, schematic view and site situation (courtesy of Ingenieurgruppe Bauen)

On the basis of the test results, a realistic design method was developed that proves a sufficient degree of post-reinforcement safety, even for previously damaged cast-iron beams. The reinforcing CFRP sheets were selected and dimensioned on this basis (Figure 19): they are $1.4 \mathrm{~mm}$ thick and $50 \mathrm{~mm}$ high.

For verification purposes, on-site confirmation tests were performed in selected trial bays after installation of the reinforcement. These tests provided impressive proof of its effectiveness. The specified service load of $5 \mathrm{kN} / \mathrm{m}^{2}$ was thus confirmed for all historic ceilings.
Works by Eisele et al. (2004) and Eisele (2006) give a more detailed account of this section.

\section{Summary}

Increasingly, construction engineers need to strike a balance between historic structural designs and modern use requirements. Although these challenges are usually mastered (virtually anything is possible from a purely technical point of view), thorough understanding of historic structures and conservation objectives is not widespread. However, such an understanding is key to successful treatment of buildings with high conservation significance. 
Engineering History and Heritage

Volume 165 Issue EH4
Reconstruction of the Neues

Museum in Berlin, Germany

Eisele and Seiler (a)

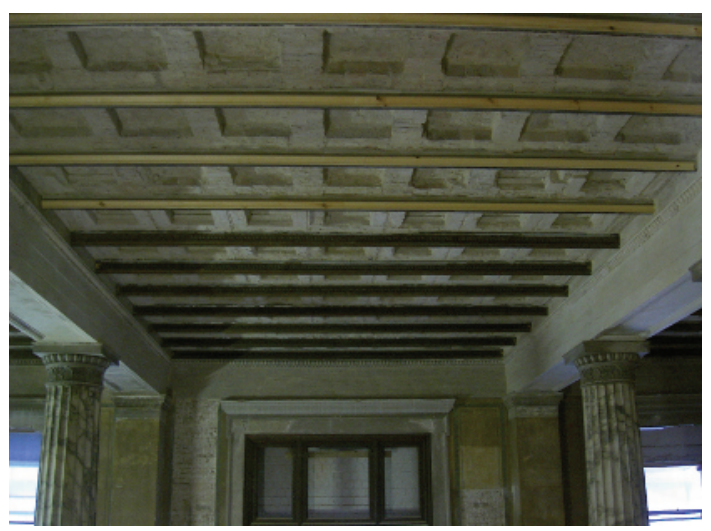

(b)
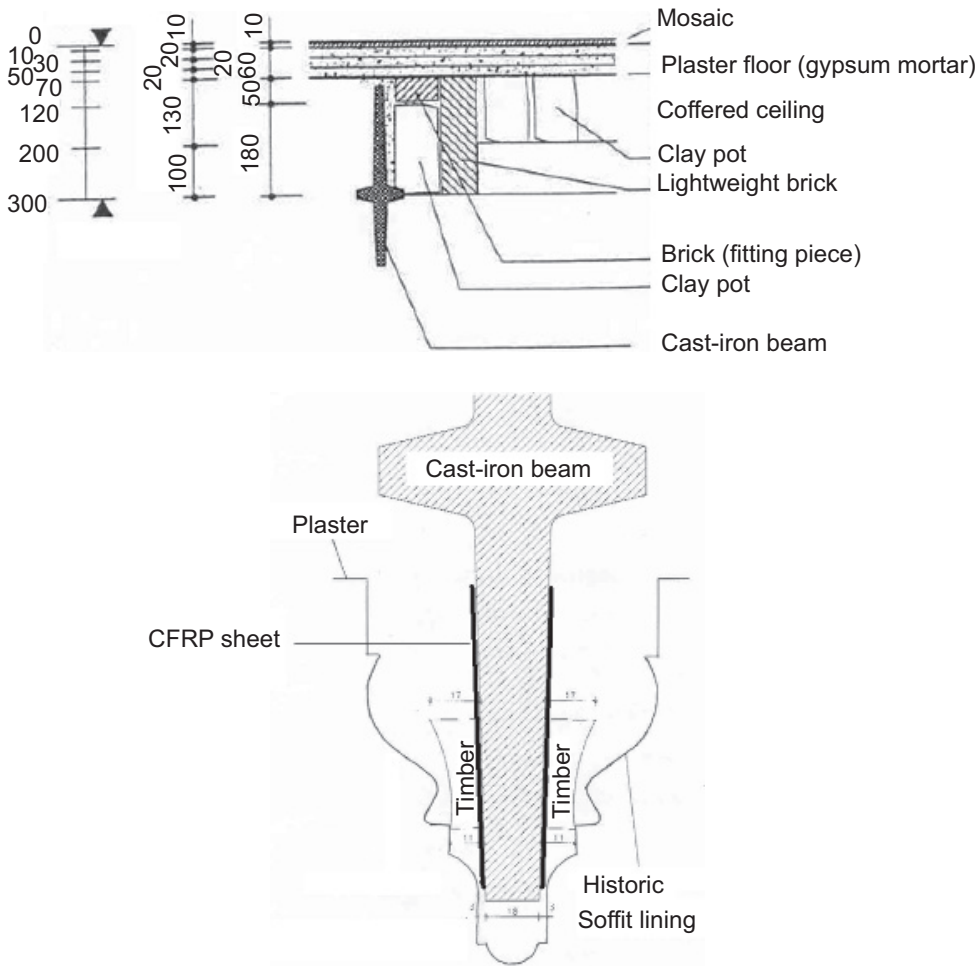

section with CFRP sheet reinforcement underneath historic soffit lining made of zinc (dimensions in $\mathrm{mm}$ ) (courtesy of Ingenieurgruppe Bauen)
Figure 17. (a) Ceiling above the vestibule; panelled ceiling consisting of clay pots between cast-iron girders after reinforcement, partly relined and (b) ceiling section and detailed

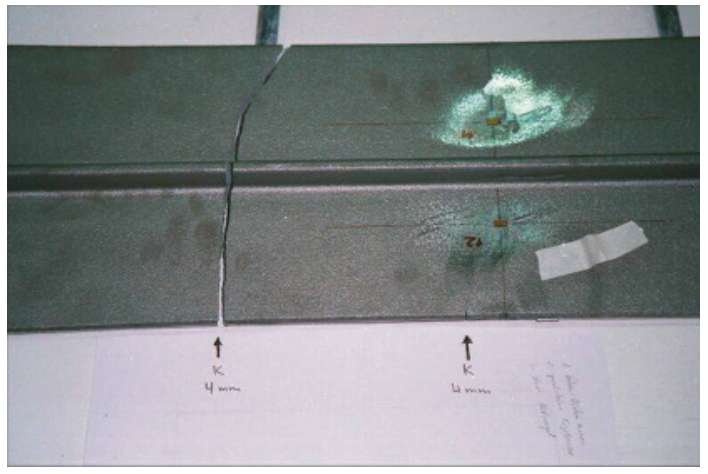

(a)

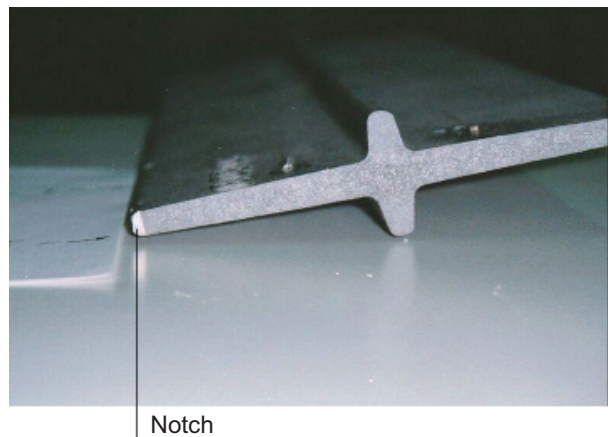

(b)

Figure 18. Fracture patterns of notched beams, notch size approximately $4 \mathrm{~mm}$. Fracture close to the notch at the point of load introduction (courtesy of Ingenieurgruppe Bauen) 


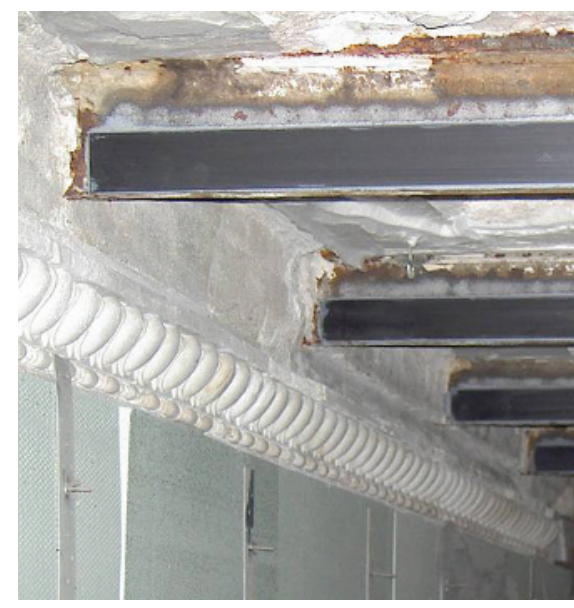

(a)

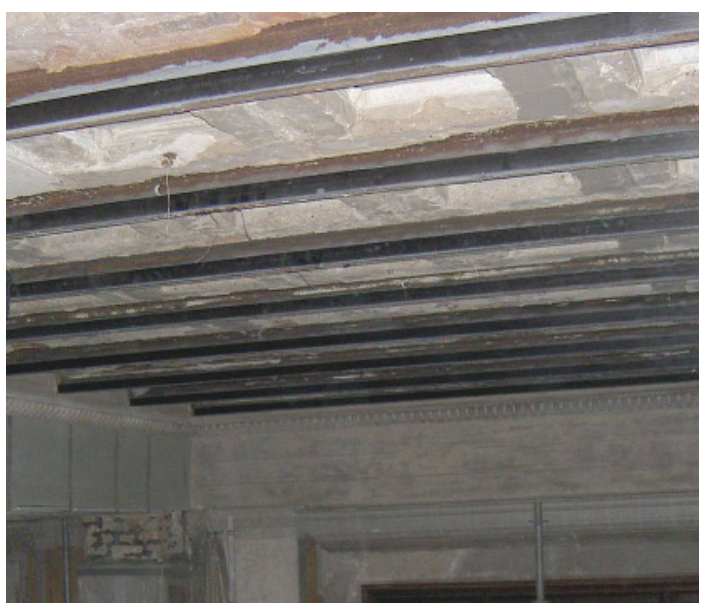

(b)

Figure 19. Example of CFRP sheet reinforcement of the ceiling above the vestibule prior to installation of the lining (courtesy of Ingenieurgruppe Bauen)

In the case reported in this paper, the most important responsibility of the engineers was to recognise, at an early stage, that purely theoretical approaches would not deliver the intended result and that all parties involved in the project - such as the client, user, architect and required experts - needed to engage in the discussions, which also had to be facilitated. Key services that needed to be provided included the development of verification concepts, the planning and design of the required tests in a cross-disciplinary approach and coordination of all the activities with the supervising authority.

\section{Acknowledgements}

Parties involved in the project were as follows.

- Client: Stiftung Preußischer Kulturbesitz and Staatliche Museen zu Berlin represented by Bundesamt für Bauwesen und Raumordnung.

- Architect: David Chipperfield Architects, London, in cooperation with Julian Harrap Architects, London.

- Structural engineers: Ingenieurgruppe Bauen, Karlsruhe, Mannheim, Berlin.

- Test engineer: Dr.-Ing. Hartmut Kalleja, Berlin.

- Experimental structural testing: Prof. Dr.-Ing. Steffens, Ingenieurgesellschaft mbH (PSI), Bremen.

\section{REFERENCES}

Eisele G (2006) Tragfähigkeitsbewertung an Natursteinsäulen am Neuen Museum in Berlin. In Natursteinsanierung Stuttgart 2006. Neue Natursteinrestaurierungsergebnisse und messtechnische Erfassungen (Grassegger G and Patitz G (eds)). Fraunhofer IRB, Stuttgart, Germany, pp. 19-28 (in German).
Eisele G and Seiler J (1999) The Berlin 'Neues Museum' - structural analysis, stabilization and structural design for restoration. In Structural Studies, Repairs and Maintenance of Historical Buildings VI (Advances in Architecture Vol. 6) (Brebbia C and Jäger W (eds)). WIT Press, Southampton, UK, pp. 767-778. Eisele G, Gutermann M, Seiler J and Steffens K (2004) Wiederaufbau des Neuen Museums in Berlin Tragwerksplanung pro Baudenkmalpflege. Bautechnik 81(6): 407-422 (in German).

Frey A and Käpplein R (1993) Beitrag zum rechnerischen Nachweis der Tragfähigkeit alter Biegeträger aus Gusseisen. Stahlbau 62(8): 221-230 (in German).

Hoffmann CW (1846) Die feuerfesten Decken des Neuen Museums hierselbst. Notizblatt des Architektenvereins Berlin (in German). Steffens K (2001) Experimentelle Tragsicherheitsbewertung von Bauwerken. Grundlagen undAnwendungsbeispiele. Ernst \& Sohn, Berlin, Germany (in German).

\section{WHAT DO YOU THINK?}

To discuss this paper, please email up to 500 words to the editor at journals@ice.org.uk. Your contribution will be forwarded to the author(s) for a reply and, if considered appropriate by the editorial panel, will be published as discussion in a future issue of the journal.

Proceedings journals rely entirely on contributions sent in by civil engineering professionals, academics and students. Papers should be 2000-5000 words long (briefing papers should be 1000-2000 words long), with adequate illustrations and references. You can submit your paper online via www.icevirtuallibrary.com/content/journals, where you will also find detailed author guidelines. 